Article

\title{
Linear-Rate Reactions for the Thermal Devolatilization of Wheat Straw Based on Pseudo-Components
}

\author{
Carmen Branca
}

Citation: Branca, C. Linear-Rate Reactions for the Thermal Devolatilization of Wheat Straw Based on Pseudo-Components. Reactions 2022, 3, 203-212. https: / / doi.org/10.3390/ reactions3010015

Academic Editors: Christophe Len and Anker Degn Jensen

Received: 14 December 2021

Accepted: 26 January 2022

Published: 7 February 2022

Publisher's Note: MDPI stays neutral with regard to jurisdictional claims in published maps and institutional affiliations.

Copyright: (C) 2022 by the author. Licensee MDPI, Basel, Switzerland. This article is an open access article distributed under the terms and conditions of the Creative Commons Attribution (CC BY) license (https:// creativecommons.org/licenses/by/ $4.0 /)$.
Istituto di Scienze e Tecnologie per l’Energia e la Mobilità Sostenibili, C.N.R., P.le V. Tecchio, 80125 Napoli, Italy; carmen.branca@stems.cnr.it; Tel.: +39-081-7682232

\begin{abstract}
Thermogravimetric curves are measured in the nitrogen of wheat straw heated up to $773 \mathrm{~K}$ with rates between $5-20 \mathrm{~K} / \mathrm{min}$. A five-step (or component) parallel reaction scheme was developed for the interpretation of the weight loss characteristics, which makes use of the lumped volatile products based on the volatiles released by the pseudo-macrocomponents. The volumetric rates show the usual Arrhenius dependence on temperature and a linear dependence on the mass fraction of the lumped volatile products. The wheat straw devolatilization mechanism consists of a single step for pseud-ocellulose (activation energies of about $180 \mathrm{~kJ} / \mathrm{mol}$ ) and two steps for the pseudohemicellulose, also including extractives, (activation energies of about 101 and $136 \mathrm{~kJ} / \mathrm{mol}$ ) and pseudo-lignin (activation energies of 189 and $126 \mathrm{~kJ} / \mathrm{mol}$ ). For the first two pseudo-macrocomponents, the activation energies were lower than those obtained through a similar approach for beech wood, owing to the much higher content of alkalis acting as catalysts for the decomposition reactions. These occur at lower temperatures and show an enhanced overlap between the pseudo-components.
\end{abstract}

Keywords: wheat straw; pyrolysis; devolatilization; TGA; kinetics

\section{Introduction}

Biomass, together with solar, wind, hydropower, and geothermal resources, can contribute significantly to a carbon-neutral and sustainable economy as it is not only the precursor of bioenergy but also biomaterials. Estimates report a biomass availability from around 1313 Mtoe in 2010 to 3271 Mtoe in 2040, thus motivating the large amount of scientific publications on related topics [1]. Biochemical and thermochemical conversion technologies are proposed, among which, pyrolysis has undoubted advantages, consisting of the possibility to tailor yields and composition of the product classes (bio-char, bio-oil and gas) according to specific needs with, in practice, no byproducts [2,3]. Among the varieties of biomass fuels, agricultural residues are quantitatively important, especially the category generically indicated as straws (wastes from cereal, protein, and oil-protein crops) [4].

Wheat is a crop widely cultivated in numerous countries and, together with maize and rice, largely contributes to human nutrition [5]; therefore, it is considered a reliable waste resource for transformation through pyrolysis processes. Previous studies examined the influence of wheat straw properties, pretreatments, and catalysts on thermogravimetric behavior and the conversion characteristics for the conditions of practical interest [4-14]. In [4], the behavior in thermogravimetry and a packed bed reactor was examined for numerous varieties of straw wastes, including that of interest here. Reference [5] examined the occurrence of alkaline compounds in straw ash and their evolution in pyrolysis. Related topics concerned the influence of water washing [6] and preloaded potassium chloride [7] on wheat straw decomposition. A comparison between this waste and other lignocellulosic fuels [8] and energy crops [9] is also available. Moderate exothermicity is shown by wheat straw pellets in a bench scale packed bed reactor uniformly heated along the lateral surface with magnitude affected by the imposed thermal irradiance [10]. Several technologies 
have been applied for wheat straw conversion, such as ablative [11], fast [12], slow [13], and acidic [14] pyrolysis. However, lumped mechanisms have not yet been proposed or investigated that are capable of predicting the formation of gaseous and vapor-phase products from the macro-components, such as in the case of wood, for instance Refs. [15-22]. Beech wood devolatilization under inert conditions was examined in relation to the role of ash [15], reaction heat [19], and as a reference fuel for the conversion of industrial hemp [22]. The thermal devolatilization of raw and torrefied spruce wood was discussed in $[17,21]$; whereas waste wood was the subject of Refs. [18,20]. A unified mechanism for beech and fir woods and some agricultural residues for the oxidative decomposition [17] is also available. Experimental methods and different modelling approaches for biomass pyrolysis were discussed extensively in reviews [2,23] and the introduction of Ref. [24]. The investigation of the decomposition kinetics is of fundamental importance for the design and development of chemical reactors using both empirical rules and advanced mathematical modeling [25-28].

In this study, thermogravimetric curves of the thermal degradation of wheat straw were measured. The data, obtained for different heating rates, were interpreted by means of a multistep kinetic model, accounting for the lumped volatile product classes evolved from extractives, hemicellulose, cellulose, and lignin. The estimation of the kinetic parameters was carried out and required invariant kinetic parameters with the heating rate, apart from the kinetic coefficients (amounts of volatiles evolved from macro-components). Results previously published for beech wood [22], taken as a standard woody biomass, were used for comparison.

\section{Materials and Methods}

\subsection{Materials}

The wheat straw sample was the waste of crops grown in Italy in the Umbria region. Before the tests, the sample was subjected to overnight drying in an oven at $373 \mathrm{~K}$. A milling process was applied (through the ball mill MM200 Retsch, Verder Scientific S.r.l., Bergamo, Italy) for obtaining particle sizes below 90 micron. The chemical composition of wheat straw, on a dry and ash-free basis, was reported [13] (Appendix A of this reference reports the method of analysis) to consist of extractives ( $8 \mathrm{wt} \%)$, hemicellulose (33 $\mathrm{wt} \%)$, cellulose $(41 \%)$, and lignin (18 wt\%). The chemical composition of beech wood [29] (extractives $(2 \mathrm{wt} \%)$, hemicellulose (33 wt \%), cellulose (45 wt \%), and lignin $(20 \mathrm{wt} \%)$ ) was comparable with that of straw apart from the lower extractive content. However, there was a huge difference between the two feedstocks in relation to their pyrolytic behavior, owing to the much higher content of alkali metals of the straw, which highly modifies the reaction paths and products $[4,22]$. The proximate analysis indeed gives ash content for the straw of $8.6 \mathrm{wt} \%$ (versus $0.4 \mathrm{wt} \%$ of beech wood), with fixed carbon (FC) and volatile matter (VM) contents of 16.9 and $74.5 \mathrm{wt} \%$, in the order [4] (corresponding FC and VM contents for beech wood of 13.1 and $86.5 \mathrm{wt} \%$ [22]).

\subsection{Thermogravimetric Analysis}

Thermogravimetric curves were measured using the commercial system Mettler TGA/1 (Mettler-Toledo S.p.A., Milano, Italy), with a pulverized sample mass of $5 \mathrm{mg}$, heated at 5,10 , and $20 \mathrm{~K} / \mathrm{min}$ up to $773 \mathrm{~K}$ under a nitrogen flow of $50 \mathrm{~mL} / \mathrm{min}$. The weight loss curves are characterized by means of parameters previously introduced $[4,16,17,19,22]$ which include: the initial degradation temperature corresponding to a mass fraction of 0.98 , $\mathrm{T}_{\text {initial }}$, the temperature $\mathrm{T}_{\text {peak }}$ of the maximum devolatilization rate, with the corresponding $-(\mathrm{dY} / \mathrm{dt})_{\text {peak }}$ and $\mathrm{Y}_{\text {peak }}, \mathrm{T}_{\text {shoulder }}$ (peak rate of shoulder in the rate curve), with the corresponding $-(\mathrm{dY} / \mathrm{dt})_{\text {shoulder }}$ and $\mathrm{Y}_{\text {shoulder }}, \mathrm{T}_{\text {offset }}$ which demarcates the beginning of the final, tailing region of the rate curve, the char yield, $\mathrm{Y}_{773}$ (the solid mass fraction detected at $773 \mathrm{~K}$ ), and the full width of the rate curve at half maximum, FWHM (temperature range). 


\section{Results and Discussion}

The results of the thermogravimetric analysis are first presented for the integral and differential curves of wheat straw and, for comparison, beech wood. Then, after a brief description of the kinetic model, the kinetic parameters and the component dynamics are presented, and comments are provided for both feedstocks. The data for beech wood are those previously determined [22].

\subsection{Thermogravimetric Characteristics}

Figure 1 reports the thermogravimetric curves of the straw and wood samples versus temperature, as measured for a heating rate of $5 \mathrm{~K} / \mathrm{min}$. As expected, though the qualitative shape of the straw curve was typical of lignocellulosic fuels, compared with wood, it was positioned at lower temperatures and exhibited a lower rate and higher char yield. It can be understood that macro-component decomposition took place with a wider overlap with respect to wood, as the first shoulder zone corresponding to hemicellulose was much less evident (the characteristic temperature cannot be univocally determined). From the quantitative point of view, the characteristic temperatures were about $27-37 \mathrm{~K}$ lower, the peak rate was lower by a factor around 1.1, and the char yield (which also included the initial ash content) was higher by a factor of about 1.6. Finally, the FWHM was slightly wider ( 50 versus $47 \mathrm{~K}$ ). In fact, the much higher alkali contents catalyzed the decomposition reactions, which occurred at lower temperatures and, in relation to primary degradation, favored charring versus devolatilization $[2,4,30,31]$. In addition, secondary cracking and polymerization of primary vapors was highly catalyzed by alkali metals [2], again favoring the formation of secondary char. As the heating rate was increased, the qualitative features of the decomposition process remained the same, but as shown by the characteristic parameters reported in Table 1, the reaction process tended to occur at successively higher temperatures and the different reaction zones became more overlapped.

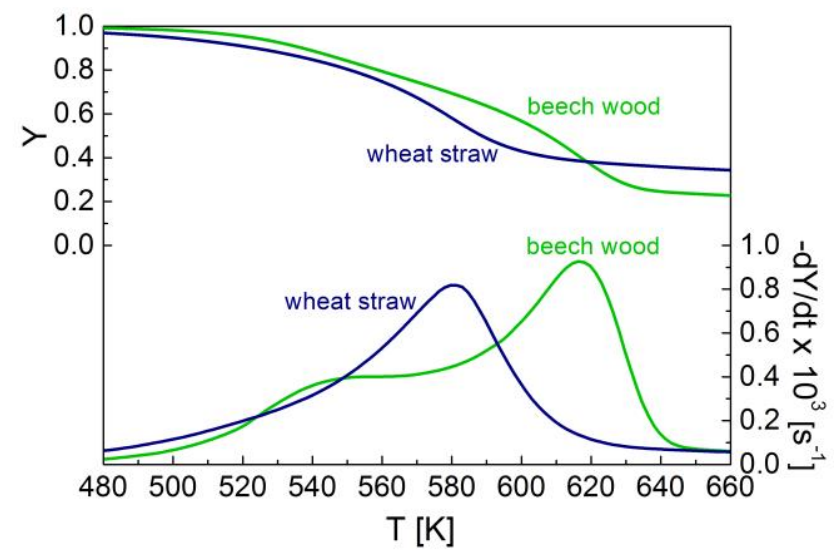

Figure 1. Mass fraction, $\mathrm{Y}$, and mass loss rate $-\mathrm{dY} / \mathrm{dt}$ for wheat straw and beech wood [22] versus temperature (heating rate $5 \mathrm{~K} / \mathrm{min}$, up to $773 \mathrm{~K}$ ).

\subsection{Kinetic Modeling}

Given the qualitative similarity between the thermogravimetric behavior of wheat straw and beech wood, it was evident that the same approach already proposed for the thermal decomposition of woody biomass [15-22] can also be applied for wheat straw. The approach refers to the contributions of the sample macro-components, where the global rate of weight loss is obtained through the superimposition of the various contributions. The kinetic analysis, however, does not permit perfectly identifying the evolution of the actual macro-components [2], so that pseudo-components are introduced. It should also be observed that the method of extraction of components, as well as the sample pretreatments, influenced the properties of the extracts, such as in the case of cellulose [32], and therefore, 
despite the approximations, the present approach was certainly adequate for the realistic prediction of the pyrolytic behavior.

Table 1. Characteristic parameters of the thermogravimetric curves for wheat straw and beech wood [22]: initial degradation temperature, $T_{\text {initial }}$, temperatures $T_{\text {peak }}$ and $T_{\text {offset }}$ at the peak and tail of the mass release rate curve, FWHM, the temperature range corresponding to the full width of the rate curve at half maximum, mass fractions, $\mathrm{Y}_{\text {peak, }}$, and rates of mass loss, $(-\mathrm{dY} / \mathrm{dt})_{\text {peak }}$, in correspondence to the peak rate and mass fraction at a temperature of $773 \mathrm{~K}$ (char yield), $\mathrm{Y}_{773}$.

\begin{tabular}{|c|c|c|c|c|c|}
\hline Sample & $\mathbf{T}_{\text {initial }}[\mathbf{K}]$ & $\begin{array}{c}\mathbf{T}_{\text {shoulder }} \\
{[\mathrm{K}]}\end{array}$ & $\mathbf{T}_{\text {peak }}[\mathrm{K}]$ & $\mathbf{T}_{\text {offset }}[\mathrm{K}]$ & FWHM [K] \\
\hline \multirow{3}{*}{$\begin{array}{l}\text { wheat } \\
\text { straw }\end{array}$} & 465 & & 580 & 612 & 46 \\
\hline & 476 & - & 590 & 619 & 46 \\
\hline & 480 & & 600 & 628 & 48 \\
\hline \multirow{4}{*}{$\begin{array}{l}\text { beech } \\
\text { wood }\end{array}$} & 502 & 558 & 617 & 639 & 47 \\
\hline & 511 & 568 & 627 & 651 & 50 \\
\hline & 517 & 576 & 638 & 663 & 54 \\
\hline & $\mathbf{Y}_{\text {shoulder }}$ & $Y_{\text {peak }}$ & $Y_{773}$ & $\begin{array}{c}-(\mathrm{dY} / \mathrm{dt})_{\text {shoulder }} \\
\times 10^{3}\left[\mathrm{~s}^{-1}\right]\end{array}$ & $\begin{array}{c}-(\mathrm{dY} / \mathrm{dt})_{\text {peak }} \\
\times 10^{3}\left[\mathrm{~s}^{-1}\right]\end{array}$ \\
\hline \multirow{3}{*}{$\begin{array}{l}\text { wheat } \\
\text { straw }\end{array}$} & & 0.58 & 0.29 & & 0.82 \\
\hline & - & 0.57 & 0.29 & - & 1.66 \\
\hline & & 0.56 & 0.28 & & 3.24 \\
\hline \multirow{3}{*}{$\begin{array}{l}\text { beech } \\
\text { wood }\end{array}$} & 0.81 & 0.41 & 0.18 & 0.40 & 0.93 \\
\hline & 0.80 & 0.41 & 0.19 & 0.77 & 1.78 \\
\hline & 0.80 & 0.40 & 0.19 & 1.56 & 3.40 \\
\hline
\end{tabular}

As it has been demonstrated [22], a set of five steps (or components) produced very accurate predictions of weight loss curves for beech wood, and the same scheme was proposed here for wheat straw. Indeed, the extractives, present in higher amounts, essentially gave rise to charred products [33]. The reaction mechanism is reported in Scheme 1:

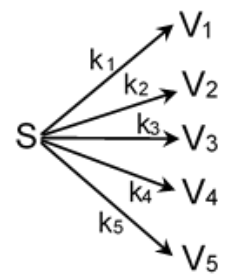

Scheme 1. Five-step parallel reaction mechanism for wheat straw decomposition.

In the Scheme $1 \mathrm{~S}$ is the sample which produces the lumped volatile products $\mathrm{V}_{\mathrm{i}}(\mathrm{i}=1$, 5). Devolatilization refers to components 1,2 for pseudo-hemicellulose, and also included extractives, component 3 for pseudo-cellulose, and components 4 and 5 for pseudo-lignin. The selection of a single step for the devolatilization of pseudo-cellulose was supported by extensive literature [2,23]. For the more complex devolatilization dynamics of pseudohemicellulose (including extractives) and pseudo-lignin, at least two steps are required [22] in view of extending the mechanism to the evaluation of DSC measurements [19].

The reaction rates took into account the dependence on temperature through the Arrhenius rate and the mass fraction of lumped volatile products by means of a linear law. This linear dependence, which is generally used by pyrolysis mechanisms, actually describes a volumetric reactive process. For instance, in char oxidation, the heterogenous rate should also take into account changes in the surface where the reaction between carbon and oxygen occurs. In this case, the surface change was generally modelled by means of a power-law dependence on the solid mass fraction [3]. Given the small sample mass and the relatively slow heating rate, the heating temperature $\mathrm{T}$, which is a known function of time, coincided with the sample temperature. Hence, the mathematical model consisted 
of five ordinary equations for the mass fractions $Y_{i}$ of the volatile fractions, whose initial values, $v_{i}$, are indicated as stoichiometric coefficients:

$$
\frac{d Y_{i}}{d t}=-A_{i} \exp \left(-\frac{E_{i}}{R T}\right) Y_{i}, Y_{i}=v_{i}, i=1, \ldots, 5
$$

The kinetic parameters were numerically estimated using the solution obtained through the routine ode15s of the software MATLAB (MathWorks Inc., Natick, MA, USA), mass conservation equations, and the simultaneous nonlinear regression of the curves for various heating rates for the minimization of the objective function (routine fminsearch).

The analysis was carried out with simultaneous consideration of integral (TG) and differential (DTG) data for various heating rates [15-17,19]. The parameters were invariant with the heating rate except for the stoichiometric coefficients which describe the possible decrease of total volatile yields as the heating rate increased. The analysis of the wheat straw data was started using the parameters already available for beech wood [22].

The results of the kinetic evaluations are summarized in Table 2 (parameters and deviations devTG and $\operatorname{dev}_{\text {DTG }}$ for the integral and differential curves $[34,35]$ ) and Figure 2, where measured and predicted integral and differential thermogravimetric curves are compared, and Figures 3-5 reported the dynamics of the five components and the pseudomacrocomponents, hemicellulose with extractives, cellulose and lignin, for a heating rate of $5 \mathrm{~K} / \mathrm{min}$ (results for beech wood are used for comparison). Both deviations and visual observation support excellent predictive capabilities of the model. With the sole exception of the activation energies for the two pseudo-lignin components (values of about 189 and $126 \mathrm{~kJ} / \mathrm{mol}$ ), the kinetic parameters are different for straw and wood decomposition. This stems from the different thermogravimetric behavior described above which originated in the first place from the different nature and composition of the inorganic fraction [36]. On the other hand, removing the water-soluble alkali compounds through hot water washing makes the behavior of the two samples more similar [37]. Yet differences can also be attributed to the different nature and content of the extractives hemicellulose and lignin, as well as to possible differences in the cellulose properties, especially the crystallinity degree [32].

Table 2. Estimated kinetic parameters (activation energy $E_{i}$ and pre-exponential factor $A_{i}(A)$ and stoichiometric coefficients $\left.v_{i}(B)\right)$ for wheat straw and beech wood [22]: components n.1,2 for pseudohemicellulose, including extractives, component $n .3$ for pseudo-cellulose, and components n.4,5 for pseudo-lignin; and corresponding deviations between measured and simulated integral ( $\left.\operatorname{dev}_{\mathrm{TG}}\right)$ and differential ( $\left.\operatorname{dev}_{\mathrm{DTG}}\right)$ curves (A).

\begin{tabular}{|c|c|c|}
\hline (A) Parameters & Straw & Beech \\
\hline $\mathrm{E}_{1}[\mathrm{~kJ} / \mathrm{mol}]$ & 101.1 & 138.8 \\
\hline $\mathrm{A}_{1}\left[\mathrm{~s}^{-1}\right]$ & $1.26 \times 10^{8}$ & $1.47 \times 10^{11}$ \\
\hline $\mathrm{E}_{2}[\mathrm{~kJ} / \mathrm{mol}]$ & 135.9 & 170.1 \\
\hline $\mathrm{A}_{2}\left[\mathrm{~s}^{-1}\right]$ & $3.30 \times 10^{10}$ & $1.91 \times 10^{13}$ \\
\hline $\mathrm{E}_{3}[\mathrm{~kJ} / \mathrm{mol}]$ & 179.8 & 194.8 \\
\hline $\mathrm{A}_{3}\left[\mathrm{~s}^{-1}\right]$ & $7.90 \times 10^{13}$ & $1.70 \times 10^{14}$ \\
\hline $\mathrm{E}_{4}[\mathrm{~kJ} / \mathrm{mol}]$ & 189.3 & 189.3 \\
\hline $\mathrm{A}_{4}\left[\mathrm{~s}^{-1}\right]$ & $8.60 \times 10^{13}$ & $4.00 \times 10^{13}$ \\
\hline $\mathrm{E}_{5}[\mathrm{~kJ} / \mathrm{mol}]$ & 125.7 & 125.7 \\
\hline $\mathrm{A}_{5}\left[\mathrm{~s}^{-1}\right]$ & $8.50 \times 10^{6}$ & $1.46 \times 10^{7}$ \\
\hline $\operatorname{dev}_{\mathrm{TG}}[\%]$ & 0.87 & 0.83 \\
\hline $\operatorname{dev}_{\text {DTG }}[\%]$ & 2.60 & 2.01 \\
\hline (B) Coefficients & Straw & Beech \\
\hline$v_{1}$ & 0.090 & 0.140 \\
\hline$v_{2}$ & 0.120 & 0.150 \\
\hline$v_{3}$ & 0.350 & 0.420 \\
\hline$v_{4}$ & 0.070 & 0.040 \\
\hline$v_{5}$ & 0.084 & 0.065 \\
\hline
\end{tabular}




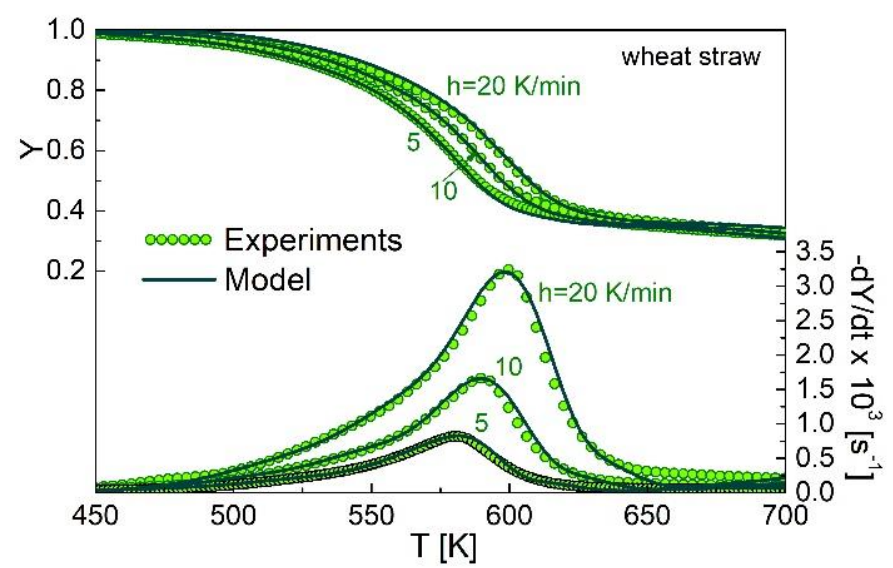

Figure 2. Comparison between predictions for wheat straw (data in Table 2) (lines) and measurements (symbols) of mass fraction $\mathrm{Y}$ and mass loss rate $-\mathrm{dY} / \mathrm{dt}$ versus temperature (heating rates 5, 10, and $20 \mathrm{~K} / \mathrm{min}$, up to $773 \mathrm{~K}$ ).

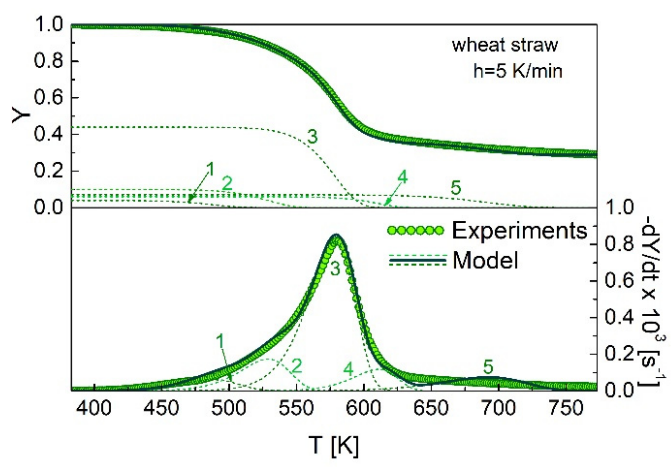

Figure 3. Predicted mass-loss rate for wheat straw (data in Table 2), $-\mathrm{dY} / \mathrm{dt}$, and predicted rates of volatile release (dashed lines) from components $\mathrm{n}$. $1-5$ versus temperature (heating rate $5 \mathrm{~K} / \mathrm{min}$, up to $773 \mathrm{~K}$ ).

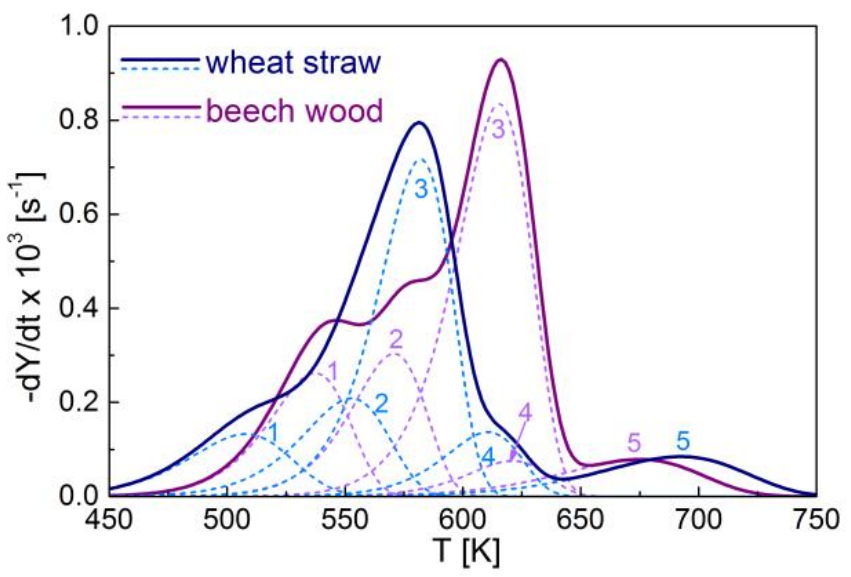

Figure 4. Predicted mass-loss rate for wheat straw and beech wood [22] (data in Table 2), $-\mathrm{dY} / \mathrm{dt}$ and predicted rates of volatile release (dashed lines) from components $n$. 1-5 versus temperature (heating rate $5 \mathrm{~K} / \mathrm{min}$, up to $773 \mathrm{~K}$ ). 


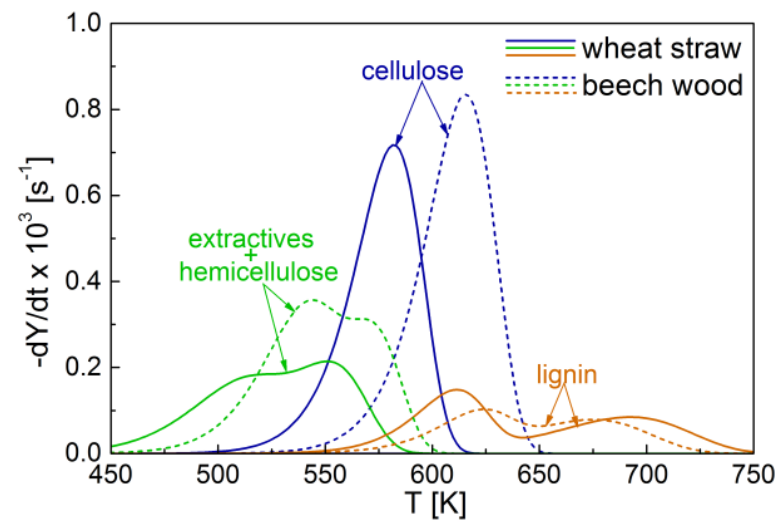

Figure 5. Predicted mass-loss rate for wheat straw (solid lines) and beech wood (dashed lines) [22] (data in Table 2), $-\mathrm{dY} / \mathrm{dt}$ from their pseudo-macrocomponents versus temperature (heating rate $5 \mathrm{~K} / \mathrm{min}$, up to $773 \mathrm{~K}$ ).

The activation energies are generally lower for the straw decomposition with respect to wood (values of 101 and $136 \mathrm{~kJ} / \mathrm{mol}$ versus 139 and $170 \mathrm{~kJ} / \mathrm{mol}$ for the overall decomposition of the low-temperature pseudo-macrocomponent, including extractives and hemicellulose), though the differences for the pseudo-cellulose decomposition are smaller (a value of about 180 with respect to $195 \mathrm{~kJ} / \mathrm{mol}$ ). These findings can be attributed to the activation of the straw reactions at lower temperatures, whereas the obvious differences in pre-exponential factors account for the different position in the peaks of the five component rates (values in the order of 507, 552, 580, 610, and $691 \mathrm{~K}$ for wheat straw versus 538,571 , 616,621 , and 675 for beech wood, given a heating rate of $5 \mathrm{~K} / \mathrm{min}$ ).

From Figure 5 (heating rate $5 \mathrm{~K} / \mathrm{min}$ ), it appears that the temperature ranges of decomposition are approximately $420-600 \mathrm{~K}, 500-620 \mathrm{~K}$, and 550-773 K (pseudo-macrocomponents hemicellulose with extractives, cellulose, and lignin in the order) for wheat straw versus the corresponding 470-610 K, 530-650 K, and 570-773 K for beech wood. For both samples, the pseudo-lignin decomposition takes place over a wide temperature range, which is also approximately the same. This result is in line with the same values of the estimated activation energies for the two components. In addition, as indicated by the largest differences in the corresponding activation energies, the differences between the two samples are significant for the low-temperature pseudo-macrocomponent. It can be hypothesized that the inclusion of a further component, maybe to only describe the decomposition of extractives, may reduce such differences. Finally, globally, the pseudo-cellulose decomposes over a temperature range of about $120 \mathrm{~K}$ wide, though for straw, it is positioned over slightly lower values.

Other important information about the conversion process was provided by the stoichiometric coefficients. As anticipated, given the small range of heating rates examined, they are constant, except for component n.5. However, also in this case, the average values can be used without significant loss of accuracy in the predictions. In accordance with the lower cellulose content, the volatile fraction related to this pseudo-component is lower for wheat straw ( 35 versus $42 \mathrm{wt} \%$ of beech wood). Moreover, the total volatiles released are 21 and $19 \mathrm{wt} \%$ from the hemicellulose and extractive pseudo-component, and 15.4 and $10.5 \mathrm{wt} \%$ from the lignin pseudo-component for straw and wood, respectively. It should be stressed that the coefficients refer to the pseudo-components; that is, the actual macro-components represent the dominant share, but the limits of the mathematical treatment and the physical overlap, enhanced by alkali metals, hinder the precise separation. Increasing the number of components for describing the evolution of the macro-components may help in separating the contributions, also taking in mind that decomposition of extractives, hemicellulose and lignin, through model compounds, is shown to be a multistep process [38-41]. 
The kinetic evaluation is carried out using curves measured for variable heating rates, which is a well-known approach to avoid compensation effects between activation energies and pre-exponential factors. The similarity in the chemical composition of beech wood and wheat straw, apart from inorganics, also supports the use of the established kinetic parameters of the former as starting values for the investigation of this study. Further corroboration about the unicity of the solution can be provided by the application of the model to different types of straws possibly associated with more widely variable thermal programs.

Further research is also needed to separate the effects of indigenous catalysts on the devolatilization rates of the straw macro-components. Washing or demineralization of the samples can be implemented for this purpose, so as to evaluate the uncatalyzed decomposition kinetics of wheat straw. Then, a new approach would represent a noticeable achievement, if capable, of modulating the effects of composition and concentration of compounds catalytically active in the ashes. The development of unified mechanisms valid for classes of biomass with similar properties, such as the case of straws of different origin, would also be very useful from both the scientific and the technological point of view.

\section{Conclusions}

The thermal devolatilization of wheat straw, similar to beech wood, can be accurately described by a five-step (component) scheme. Two components were introduced for the lumped macropseudo-extractives/hemicellulose component consisting of extractives and hemicellulose, and pseudo-lignin, whereas a single component suffices for pseudo-cellulose. However, important differences are observed between the behavior of wheat straw and beech wood.

The activation energies for the two components describing the evolution of pseudohemicellulose (and extractives) were significantly lower for wheat straw. Moreover, the pseudo-cellulose also decomposed with a slightly lower activation energy (about 180 versus $195 \mathrm{~kJ} / \mathrm{mol}$ ). These findings were attributable to the strong catalytic action exerted by the indigenous alkali compound, present in much higher amounts in wheat straw, on the thermal decomposition of holocellulose. On the other hand, the activation energies for the decomposition of the two components of the pseudo-lignin are the same.

Funding: This research received no external funding.

Data Availability Statement: All data generated or analysed during this study are included in this published article and in the cited literature.

Conflicts of Interest: The author declare no conflict of interest.

\section{References}

1. Manzano-Agugliaro, F.; Alcayde, A.; Montoya, F.G.; Zapata-Sierra, A.; Gil, C. Scientific production of renewable energies worldwide: An overview. Renew. Sustain. Energy Rev. 2013, 18, 134-143. [CrossRef]

2. Di Blasi, C. Modeling chemical and physical processes of wood and biomass pyrolysis. Prog. Energy Combust. Sci. 2008, 34, 47-90. [CrossRef]

3. Di Blasi, C. Combustion and gasification rates of lignocellulosic chars. Prog. Energy Combust. Sci. 2009, 35, 121-140. [CrossRef]

4. Branca, C.; Di Blasi, C.; Galgano, A. Pyrolytic conversion of wastes from cereal, protein and oil-protein crops. J. Anal. Appl. Pyrolysis 2017, 127, 426-435. [CrossRef]

5. Zhang, Y.; Xie, X.; Zhao, J.; Wei, X. The alkali metal occurrence characteristics and its release and conversion during wheat straw pyrolysis. Renew. Energy 2020, 151, 255-262. [CrossRef]

6. Jensen, A.; Dam-Johansen, K. TG-FTIR Study of the influence of potassium chloride on wheat straw pyrolysis. Energy Fuels 1998, 12, 929-938. [CrossRef]

7. Di Blasi, C.; Branca, C.; D'Errico, G. Degradation characteristics of straw and washed straw. Thermochim. Acta 2000, 364, 133-142. [CrossRef]

8. Di Blasi, C.; Branca, C.; Galgano, A. Biomass screening for the production of furfural via thermal decomposition. Ind. Eng. Chem. Res. 2010, 49, 2658-2671. [CrossRef]

9. Butler, E.; Devlin, G.; Meier, D.; McDonnell, K. Characterization of spruce, salix, miscanthus and wheat straw for pyrolysis applications. Bioresour. Technol. 2013, 131, 202-209. [CrossRef] 
10. Di Blasi, C.; Branca, C.; Sarnataro, F.E.; Gallo, A. Thermal runaway in the pyrolysis of some lignocellulosic biomasses. Energy Fuels 2014, 28, 2684-2696. [CrossRef]

11. Gómez-Monedero, B.; Bimbela, F.; Arauzo, J.; Faria, J.; Ruiz, M.P. Pyrolysis of Red Eucalyptus, Camelina straw, and wheat straw in an ablative reactor. Energy Fuels 2015, 29, 1766-1775. [CrossRef]

12. Fonseca, F.G.; Funke, A.; Niebel, A.; Soares Dias, A.P.; Dahmen, N. Moisture content as a design and operational parameter for fast pyrolysis. J. Anal. Appl. Pyrolysis 2019, 139, 73-86. [CrossRef]

13. Greco, G.; Di Stasi, C.; Rego, F.; Gonzalez, B.; Manya, J.J. Effects of slow-pyrolysis conditions on the products yields and properties and on exergy efficiency: A comprehensive assessment for wheat straw. Appl. Energy 2020, 279, 115842. [CrossRef]

14. Verma, R.; Verma, S.K.; Verma, S.; Wang, J.; Liu, J.; Jing, B.; Rakesh, K.P. Value-addition of wheat straw through acid treatment and pyrolysisof acid treated residues. J. Clean. Prod. 2021, 282, 124488. [CrossRef]

15. Branca, C.; Albano, A.; Di Blasi, C. Critical evaluation of wood devolatilization mechanisms. Thermochim. Acta 2005, 429, 133-141. [CrossRef]

16. Brostrom, M.; Nordin, A.; Pommer, L.; Branca, C.; Di Blasi, C. Influence of torrefaction on the devolatilization and oxidation kinetics of wood. J. Anal. Appl. Pyrolysis 2012, 96, 100-109. [CrossRef]

17. Branca, C.; Di Blasi, C. A unified mechanism of the combustion reactions of lignocellulosic fuels. Thermochim. Acta 2013, 565, 58-64. [CrossRef]

18. Moreno, A.I.; Font, R. Pyrolysis of furniture wood waste: Decomposition and gases evolved. J. Anal. Appl. Pyrolysis 2015, 113, 464-473. [CrossRef]

19. Branca, C.; Di Blasi, C. A summative model for the pyrolysis reaction heats of beech wood. Thermochim. Acta 2016, 638, 10-16. [CrossRef]

20. Moreno, A.I.; Font, R.; Conesa, J.A. Combustion of furniture wood waste and solid wood: Kinetic study and evolution of pollutants. Fuel 2017, 192, 169-177. [CrossRef]

21. Barta-Rajnai, E.; Várhegyi, G.; Wang, L.; Skreiberg, Ø.; Grønli, M.; Czégény, Z. Thermal decomposition kinetics of wood and bark and their torrefied products. Energy Fuels 2017, 31, 4024-4034. [CrossRef]

22. Branca, C.; Di Blasi, C. Thermal degradation behavior and kinetics of industrial hemp stalks and shives. Thermochim. Acta 2021, 697, 178878. [CrossRef]

23. White, J.E.; Catallo, W.J.; Legendre, B.L. Biomass pyrolysis kinetics: A comparative critical review with relevant agricultural residue case studies. J. Anal. Appl. Pyrolysis 2011, 91, 1-33. [CrossRef]

24. Amutio, M.; Lopez, G.; Alvarez, J.; Moreira, R.; Duarte, G.; Nunes, J.; Olazar, M.; Bilbao, J. Pyrolysis kinetics of forestry residues from the Portuguese Central Inland Region. Chem. Eng. Res. Des. 2013, 91, 2682-2690. [CrossRef]

25. Galgano, A.; Di Blasi, C.; Horvat, A.; Sinai, Y. Experimental validation of a coupled solid- and gas-phase model for combustion and gasification of wood logs. Energy Fuels 2006, 20, 2223-2232. [CrossRef]

26. Di Blasi, C.; Branca, C. Modeling a stratified downdraft wood gasifier with primary and secondary air entry. Fuel 2013, 104, 847-860. [CrossRef]

27. Galgano, A.; Di Blasi, C.; De Vita, R. Experimental validation of a wood burning model. Energy Fuels 2018, 32, 8494-8506. [CrossRef]

28. Zachl, A.; Buchmayr, M.; Gruber, J.; Anca-Couce, A.; Scharler, R.; Hochenauer, C. Evaluation and extension of the load and fuel flexibility limits of a stratified downdraft gasifier. Energy 2022, 239, 122279. [CrossRef]

29. Di Blasi, C.; Branca, C.; Masotta, F.; De Biase, E. Experimental analysis of reaction heat effects during beech wood pyrolysis. Energy Fuels 2013, 27, 2665-2674. [CrossRef]

30. Di Blasi, C.; Branca, C.; Galgano, A. Influences of potassium hydroxide on the rate and thermicity of wood pyrolysis reactions. Energy Fuels 2017, 1, 6154-6162. [CrossRef]

31. Di Blasi, C.; Branca, C.; Galgano, A. Role of the potassium chemical state in the global exothermicity of wood packed-bed pyrolysis. Ind. Eng. Chem. Res. 2018, 57, 11561-11571. [CrossRef]

32. Gonzalez Martinez, M.; Marlin, N.; Da Silva Perez, D.; Dupont, C.; del Mar Saavedra Rios, C.; Meyer, X.-M.; Gourdon, C.; Mortha, G. Impact of cellulose properties on its behavior in torrefaction: Commercial microcrystalline cellulose versus cotton linters and celluloses extracted from woody and agricultural biomass. Cellulose 2021, 28, 4761-4779. [CrossRef]

33. Di Blasi, C.; Branca, C.; Santoro, A.; Perez Bermudez, R.A. Weight loss dynamics of wood chips under fast radiative heating. J. Anal. Appl. Pyrolysis 2001, 57, 77-90. [CrossRef]

34. Branca, C.; Di Blasi, C.; Horacek, H. Analysis of the combustion kinetics and the thermal behavior of an intumescent system. Ind. Eng. Chem Res. 2002, 41, 2107-2114. [CrossRef]

35. Branca, C.; Di Blasi, C. Self-heating effects in the thermogravimetric analysis of wood char oxidation. Fuel 2020, $276,118012$. [CrossRef]

36. Vassilev, S.V.; Baxter, D.; Andersen, L.K.; Vassileva, C.G. An overview of the chemical composition of biomass. Fuel 2010, 89, 913-933. [CrossRef]

37. Branca, C.; Di Blasi, C.; Galgano, A. Experimental analysis about the exploitation of industrial hemp (Cannabis sativa) in pyrolysis. Fuel Proc. Technol. 2017, 162, 20-29. [CrossRef]

38. Di Blasi, C.; Lanzetta, M. Intrinsic kinetics of isothermal xylan degradation in inert atmosphere. J. Anal. Appl. Pyrolysis 1997, 40, 287-303. [CrossRef] 
39. Varhegyi, G.; Gronli, M.G.; Di Blasi, C. Effects of sample origin, extraction and hot water washing on the devolatilization kinetics of chestnut wood. Ind. Eng. Chem. Res. 2004, 43, 2356-2367. [CrossRef]

40. Branca, C.; Di Blasi, C.; Mango, C.; Hrablay, I. Products and kinetics of glucomannan pyrolysis. Ind. Eng. Chem. Res. 2013, 52, 5030-5039. [CrossRef]

41. Yang, H.; Yan, R.; Chen, H.; Lee, D.H.; Zheng, C. Characteristics of hemicellulose, cellulose and lignin pyrolysis. Fuel 2007, 86, 1781-1788. [CrossRef] 